\title{
Effects of organic and inorganic fertilization on yield and quality of processing tomato (Lycopersicon esculentum Mill.)
}

\author{
Dimitrios Bilalis $^{1 *}$, Magdalini Krokida ${ }^{2}$, Ioannis Roussis ${ }^{1}$, \\ Panayiota Papastylianou ${ }^{I}$, Ilias Travlos ${ }^{I}$, Nikolina Cheimona ${ }^{I}$, Argyro Dede ${ }^{I}$ \\ ${ }^{1}$ Laboratory of Agronomy, Department of Crop Science, School of Agriculture, Engineering and Environmental \\ Sciences, Agricultural University of Athens, 75 Iera Odos Str., 11855 Athens, Greece \\ ${ }^{2}$ Laboratory of Process Analysis and Design, School of Chemical Engineering, National Technical University \\ of Athens, 9 Heroon Polytechniou Str., 15780 Athens, Greece
}

\begin{abstract}
The demand for organically grown products is increasing because many people are concerned about the environment and believe that organic products are healthier than conventional ones. Some studies have shown that organically produced tomato fruits contain higher levels of antioxidants, polyphenols and carotenoids than those produced conventionally. The objective of this study was to evaluate the influence of organic and inorganic fertilization on agronomic and quality characteristics of the processing tomato. The 2-year experiment was laid out in a randomized complete block design, with three replications and three fertilization treatments (untreated, compost and inorganic fertilizer). The results showed that the highest fruit number per plant (98.5), average fruit weight $(63.6 \mathrm{~g})$ and fruit yield $\left(168.0 \mathrm{tha}^{-1}\right)$ were obtained under inorganic fertilization. The highest total soluble solids ( $4.39^{\circ}$ Brix) and total soluble solids to titratable acidity ratio (17.4), $L^{*}(43.4)$ and $a^{*}(35.4)$ values, as well as the highest lycopene content $\left(88.5 \mathrm{mg} \mathrm{kg}^{-1} \mathrm{f} . \mathrm{w}\right)$. were achieved through the application of organic fertilizer. Significantly higher total soluble solids and total soluble solids to titratable acidity ratio in organically grown tomatoes are particularly important to the processing tomato industry. Finally, the highest lycopene content produced under organic fertilization as well as the non-significant difference between the organic and conventional tomatoes in terms of lycopene yield make organic processing tomatoes suitable for lycopene production.
\end{abstract}

Keywords: compost, Heinz $3402 \mathrm{~F}_{1}$, lycopene, surface colour, total soluble solids

\section{INTRODUCTION}

Tomato (Lycopersicon esculentum Mill.) constitutes one of the most valuable horticultural crops, not only because of its economic importance, but also for its sensory qualities and nutritional value. It is consumed in the form of fresh as well as processed products. More than $80 \%$ of tomatoes grown throughout the world are processed into products such as sauce, juice, ketchup, canned tomato, stew and soup (Viskelis et al., 2015).

Epidemiological studies have proved the importance of tomato and its products in reducing various ailments because they contain high amounts of antioxidants such as carotenoids, polyphenols, ascorbic acid and many others (Perveen et al., 2015). Lycopene is the most plentiful carotene in the tomato fruit, comprising up to $90 \%$ of the total

*Corresponding author. 
carotenoids present (Viskelis et al., 2015), and is the most important antioxidant with a high oxygen free radical-scavenging and quenching capacity, and thus provides protection against chronic diseases, such as several types of cancer, including cancer in the mouth, pharynx, esophagus, stomach and large intestine, and cardiovascular diseases (Perveen et al., 2015). Lycopene is also the pigment mainly responsible for the red colour of tomato fruits. Various studies have reported that the lycopene content in tomatoes is most notably influenced by various genetic and environmental factors, such as the cultivar, growing season, cultivation conditions and harvesting stage (Toor et al., 2006; Rickman Pieper and Barrett, 2008).

Successful production of processing tomato requires to increase both yield and fruit quality. There has been a substantial research effort devoted to the processing tomato; however, it is not clear how the environment, cropping techniques and crop management affect each of the fruit characteristics measured at harvest to estimate the quality of processed products. In addition, during the last decades, the demand for organically grown products has increased because many people are concerned about the environment and believe that organic products are healthier than the conventional ones (Riahi et al., 2009). Several experiments investigating the differences in growth and quality parameters between organically and conventionally grown tomatoes have been conducted lately (Chassy et al., 2006; Rickman Pieper and Barrett, 2008; Riahi et al., 2009; Bilalis et al., 2013; Cheimona et al., 2016). Some studies have shown that organically produced tomato fruits contain higher amounts of antioxidants, total phenolics and ascorbic acid (Toor et al., 2006), and more total soluble solids (Chassy et al. 2006; Rickman Pieper and Barrett, 2008) compared to conventionally grown tomatoes, but not all studies have been in agreement in this respect.

The increased interest in the organic production of processing tomato enforced the need to evaluate the yield and quality parameters of organic tomato. The objective of this study was therefore to evaluate the effects of organic and inorganic fertilization on agronomic and quality characteristics of processing tomatoes.

\section{MATERIAL AND METHODS}

\section{Site and experimental design}

A processing tomato crop (Lycopersicon esculentum Mill. 'Heinz 3402' $F_{1}$ ) was established in the organic experimental field of the Agricultural University of Athens (Latitude: $37^{\circ} 59^{\prime} 1.70^{\prime \prime} \mathrm{N}$, Longitude: $23^{\circ} 42^{\prime} 7.04^{\prime \prime} \mathrm{E}$, Altitude: $29 \mathrm{~m}$ above sea level) during 2014 and 2016. The soil was a clay loam ( $29.8 \%$ clay, $34.3 \%$ silt and $35.9 \%$ sand) with $\mathrm{pH}\left(1: 1 \mathrm{H}_{2} \mathrm{O}\right) 7.29$, nitrate-nitrogen $\left(\mathrm{NO}_{3}-\mathrm{N}\right)$ $12.4 \mathrm{mg} \mathrm{kg}^{-1}$ soil, available phosphorus (P) 13.2 mg kg-1 soil, available potassium (K) $201 \mathrm{mg} \mathrm{kg}^{-1}$ soil, $15.99 \% \mathrm{CaCO}_{3}$ and $1.47 \%$ organic matter. The site was managed according to organic agricultural guidelines (EC 834/2007). Weather data (mean monthly temperature and precipitation) pertaining to the years 2014 and 2016 were obtained from the meteorological station of the Agricultural University of Athens and are presented in Figure 1.

The experiment was set up on an area of $322 \mathrm{~m}^{2}$ according to a randomized complete block design (RCBD), with three fertilization treatments:

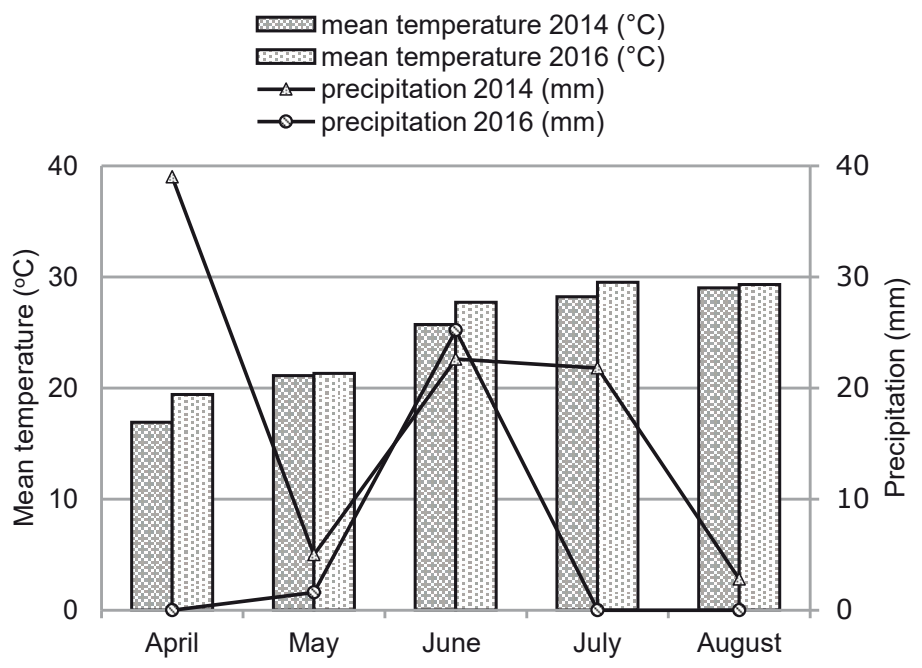

Figure 1. Weather data (mean monthly temperature and precipitation) during the experimental periods (April-August, 2014 and 2016) 
control (untreated), seaweed compost (2000 kg ha $^{-1}$ Posidonia 1-2\% N, Compost Hellas S.A.), and inorganic fertilizer (360 $\mathrm{kg} \mathrm{ha}^{-1}$ Enpeka $15-15-15+5$ $\mathrm{S}$, Compo $\mathrm{GmbH}$ ), and 3 replications for each treatment. The plot size was $28 \mathrm{~m}^{2}(7 \mathrm{~m} \times 4 \mathrm{~m})$. There was a space of $1 \mathrm{~m}$ between replications and $1 \mathrm{~m}$ between plots. One day before transplanting, the fertilizers were applied by hand to the soil surface and then harrowed in. Transplanting of tomato seedlings into the field was done on 15 April 2014 and 22 April 2016. Tomato seedlings were transplanted by hand in rows $60 \mathrm{~cm}$ apart. Transplants were set at $60 \mathrm{~cm}$ between each other. The total quantity of water applied during the experiment was 745 and $964 \mathrm{~mm}$ in 2014 and 2016, respectively. Weeds were controlled by hand hoeing when it was necessary.

\section{Sampling, measurements and methods}

Dry weight per plant was measured using four randomly selected plants in each plot at 99 days after transplanting (DAT). The dry weight was determined after drying for 72 hours at $64^{\circ} \mathrm{C}$. Fruit number per plant was counted at 112 DAT on four randomly selected tomato plants from each plot. Fruit yield, average fruit weight and fruit diameter were also determined at 112 DAT by manually harvesting the plants that were in the selected rows of the plots used for counting the number of fruits per plant. Fruit diameter $(\mathrm{mm})$ was measured with a Starrett EC799A-6/150 electronic digital caliper (L.S. Starrett Co., Athol, MA, USA) having an accuracy of $0.02 \mathrm{~mm}$.

For the determination of fruit surface colour, firmness and total soluble solids (TSS) content, samples of fruits were collected at 99 DAT. Three fruits per plant from three randomly selected plants per plot (nine fruits per plot) were used for these measurements.

Fruit surface colour measurements were performed with a Minolta CR-300 tristimulus colorimeter (Konica Minolta, Inc., Sakai, Osaka 590-8551, Japan) calibrated against a white standard calibration plate $(\mathrm{Y}=93.9 ; \mathrm{x}=0.3134 ; \mathrm{y}=0.3208)$. Colour was recorded according to the CIE- $L * a * b *$ colour space system. Two measurements were made at the equatorial region of the pericarp of each fruit and the mean values were determined.

Colour index (CI) shows a high correlation with the external visual colour of the fruits and was calculated with the following equation described by Jimenez-Cuesta et al. (1981):

$$
\mathrm{CI}=1000 a^{*} L^{*-1} b^{*-1}
$$

Hue angle $\left(h^{\circ}\right)$, the qualitative attribute of colour, is used to define the difference between a certain colour and a grey colour with the same lightness, and was computed with the following equation (Little, 1975):

$$
h^{\circ}=\tan ^{-1}\left(b^{*} a^{*-1}\right)
$$

Chroma $\left(C^{*}\right)$, the Euclidean norm of the $a^{*}$, $b^{*}$ vector, represents colour saturation and was determined using the equation described by McGuire (1992), as given below:

$$
C^{*}=\left(a^{* 2}+b^{* 2}\right)^{0.5}
$$

Colour difference with true red (DE), the Euclidean distance from any colour locus related to the true red colour (coordinates: $L^{*}=50, a^{*}=+60$, $b^{*}=0$ ), was obtained by the following equation (López Camelo and Gómez, 2004):

$$
\mathrm{DE}=\left[\left(L^{*}-50\right)^{2}+\left(a^{*}-60\right)^{2}+b^{* 2}\right]^{0.5}
$$

The $a^{*} / b^{*}$ ratio can be used to report the brightness of the red colour of the tomato fruit and its products (Akdeniz et al., 2012).

Fruit firmness was measured at the equatorial region of the fruit by recording the force required to insert a $6.3 \mathrm{~mm}$-diameter conical needle to a depth of $0.6 \mathrm{~cm}$ in the fruit using a Chatillon DFIS 10 penetrometer connected to a Chatillon TCM 201-M motorized force test stand (John Chatillon and Sons, Inc., Greensboro, NC 27425, USA) and moving at a constant speed of $200 \mathrm{~mm} \mathrm{~min}^{-1}$.

Total soluble solids (TSS) content was measured at $20^{\circ} \mathrm{C}$ with a Schmidt \& Haensch HR32B handheld refractometer (Schmid \& Haensch GmbH \& Co., 13403 Berlin, Germany) having a sensitivity of $0.2^{\circ}$ Brix.

Titratable acidity (TA) was determined on two mature fruits from two randomly selected plants per plot by titrating $10 \mathrm{ml}$ of diluted tomato pulp with $\mathrm{N} / 50 \mathrm{NaOH}$ using $1 \%$ phenolphthalein $(1 \mathrm{~g}$ phenolphthalein in $100 \mathrm{~mL}$ of $95 \%$ ethyl alcohol) as indicator and the result was expressed in percentage citric acid (Egan et al., 1981). In addition, the TSS/ TA ratio, an index of food maturity, was also calculated (Sadler and Murphy, 2010).

For lycopene assessment, fruit samples (one fruit per plot) were selected and weighed at harvest (112 DAT) and then homogenized in a household mixer and dehydrated for $48 \mathrm{~h}$ using a Lyovac GT 2 freeze-dryer (Leybold-Heraeus $\mathrm{GmbH}$, Köln, Germany) under vacuum. The freeze-dried samples were ground in a laboratory mill in order to obtain tomato flour. $0.5 \mathrm{~g}$ of the flour was used for lycopene extraction. The extraction was performed using ultrasonic-assisted extraction (UAE) with 
response surface methodology (RSM) and modified as described by Eh and Teoh (2012). An XO-SM50 Ultrasonic Microwave Reaction System (Nanjing Xianou Instruments Manufacture co., Ltd., Nanjing City, China) was used for the extraction. A mixture of solvents consisting of n-hexane : methanol : acetone $(2: 1: 1 \mathrm{v} / \mathrm{v})$ and containing $0.05 \%(\mathrm{w} / \mathrm{v})$ butylated hydroxytoluene (BHT) was applied to extract lycopene (and carotenoids) from the tomato flour sample. The sample $(0.5 \mathrm{~g})$ was placed in a $150-\mathrm{mL}$ flask, and $50 \mathrm{~mL}$ of the solvent mixture was added to achieve 1:100 (w/v) ratio. An ultrasonic probe was immersed into the solution to a depth of $7 \mathrm{~cm}$ from the top of the flask. The ultrasonic power level and ultrasonic frequency were $140 \mathrm{~W}$ and $25 \mathrm{kHz}$, respectively. Moreover, the temperature of samples was kept at $45 \pm 5^{\circ} \mathrm{C}$ by using an indirect cold-water circulation system. Quantitative analysis of lycopene extracted during the ultrasonic-assisted extraction was carried out by high-performance liquid chromatography (HPLC). The analysis was performed using a Hewlett-Packard 1100 system composed of an HP 1100 Quaternary Pump, an Agilent 1100 Series Micro Vacuum Degasser, a Rheodyne model 7010 Sample Injector and an HP 1100 Series Diode Array Detector (DAD). The HPLC system was equipped with a $\mathrm{YMC} \mathrm{C}_{30}$ column (250 $\times 4.6 \mathrm{~mm}$ I.D., $5 \mu \mathrm{m}$ particle, Tokyo, Japan). Mobile phase consisted of three solvents, (A) acetonitrile, (B) 1-butanol and (C) methylene chloride (Lee and Chen, 2011). Separation of compounds was carried out with the following gradient elution profile: 0 min, A:B:C 69.3:29.7:1; 10 min, A:B:C 67.2:28.8:4; 20 min, A:B:C 61.6:26.4:12; 40 min, A:B:C 49:21:30; $50 \mathrm{~min}$. Chromatography was performed at $25^{\circ} \mathrm{C}$ with the flow rate maintained at $2 \mathrm{~mL} \mathrm{~min}^{-1}$. UV traces were measured at 472 and $503 \mathrm{~nm}$, and UVvisible spectra were obtained between 250 and $600 \mathrm{~nm}$. Concentration of lycopene was calculated using the extinction coefficient of $17.2 \times 10^{4} \mathrm{M}^{-1} \mathrm{~cm}^{-1}$ at $503 \mathrm{~nm}$ (Fish et al. 2002). The lycopene content was expressed as $\mathrm{mg} \mathrm{kg}^{-1}$ fresh weight (Sadler et al., 1990). The lycopene yield was calculated by multiplying the lycopene content by the fruit yield.

\section{Statistical analysis}

The experimental data were analyzed using the SigmaPlot 12 statistical software (Systat Software Inc., San Jose, CA, USA). The trait data produced by the fertilization treatments in the two years were analyzed by adopting a $2 \times 3$ factorial design (two years $\times$ three fertilization treatments) laid out in a randomized complete block design (RCBD) with three replications. The Analysis of Variance (ANOVA) used a mixed model, with years and replications as random effects and fertilization as fixed effect. Differences between means were separated using Tukey's honestly significant difference test (Tukey's HSD). Correlation analyses were used to describe the relationships between growth parameters, yield components and quality characteristics using Pearson's correlation. All comparisons were made at the 5\% level of significance.

\section{RESULTS AND DISCUSSION}

\section{Dry weight per plant}

The dry weight of the above-ground parts of the processing tomato plant is presented in Table 1 . The effect of fertilization was found to be statistically significant throughout the experimental periods. In particular, the highest dry weight was achieved in the plots fertilized with the inorganic fertilizer, with the values ranging from $155.0 \mathrm{~g}$ (2016) to $171.1 \mathrm{~g}$ (2014). The lowest values occurred in the unfertilized treatment (95.1 and $96.2 \mathrm{~g}$ in 2014 and 2016, respectively). Generally, several studies have reported that the tomato crop presents a positive response to inorganic nitrogen fertilization. Elia and Conversa (2012) obtained 9.9, 11.1, 12.9 and $13.3 \mathrm{Mg}$ $\mathrm{ha}^{-1}$ of above-ground biomass for plants fertilized with $0,100,200$ and $300 \mathrm{~kg} \mathrm{~N}^{-1}$, respectively. Nitrogen fertilization had a positive impact on vegetative growth and biomass accumulation, as it is associated with increasing photosynthate source capacity (Tei et al., 2002).

\section{Fruit number per plant}

The number of fruits per plant was significantly influenced by the different fertilization regimes (Tab. 1). During the 2-year experiment, the highest mean number (98.5) was achieved in the inorganic treatment, while the lowest mean number (79.3) was obtained in the control. This finding is in line with the report by Tonfack et al. (2009), where the application of inorganic fertilization resulted in a higher number of fruits per plant than under organic fertilization. Contrary to this, Rinaldi et al. (2007) had stated that the number of fruits per plant was not affected by the different types of organic and mineral nitrogen fertilizers, with the values ranging from 46.2 to 47.1 for all the treatments. In general, the apparent deficiency of an adequate supply of plant-available $\mathrm{N}$ from organic fertilizers, resulting from a slow rate of mineralization, makes the crop 
Table 1. Effect of fertilization (control, compost, inorganic fertilizer) on dry weight per plant, fruit number per plant, fruit yield and average fruit weight by Tukey's HSD test

\begin{tabular}{|c|c|c|c|c|}
\hline Fertilization & $\begin{array}{l}\text { Dry weight per plant } \\
(\mathrm{g})\end{array}$ & $\begin{array}{l}\text { Fruit number } \\
\text { per plant }\end{array}$ & $\begin{array}{l}\text { Fruit yield } \\
\left(\mathrm{t} \mathrm{ha}^{-1}\right)\end{array}$ & $\begin{array}{l}\text { Average fruit weight } \\
(\mathrm{g})\end{array}$ \\
\hline \multicolumn{5}{|l|}{ Experiment 2014} \\
\hline Control & $95.1 \pm 17.8 \mathrm{~b}$ & $78.1 \pm 4.9 \mathrm{~b}$ & $125.4 \pm 11.1 \mathrm{~b}$ & $43.4 \pm 10.0 \mathrm{~b}$ \\
\hline Compost & $153.3 \pm 24.7 \mathrm{ab}$ & $86.5 \pm 7.2 \mathrm{ab}$ & $149.1 \pm 8.5 \mathrm{ab}$ & $50.2 \pm 8.1 \mathrm{ab}$ \\
\hline Inorganic fertilizer & $171.1 \pm 32.8 \mathrm{a}$ & $101.8 \pm 7.0 \mathrm{a}$ & $174.8 \pm 18.7 \mathrm{a}$ & $64.8 \pm 4.4 \mathrm{a}$ \\
\hline$F_{\text {fertilization }}$ & $*$ & $*$ & $* *$ & $*$ \\
\hline \multicolumn{5}{|l|}{ Experiment 2016} \\
\hline Control & $96.2 \pm 7.9 \mathrm{c}$ & $80.6 \pm 1.2 \mathrm{~b}$ & $123.0 \pm 16.5 \mathrm{~b}$ & $55.7 \pm 2.4 \mathrm{a}$ \\
\hline Compost & $129.4 \pm 11.9 \mathrm{~b}$ & $89.8 \pm 2.6 \mathrm{a}$ & $150.3 \pm 13.6 \mathrm{ab}$ & $59.2 \pm 4.4 \mathrm{a}$ \\
\hline Inorganic fertilizer & $154.95 \pm 14.3 \mathrm{a}$ & $95.2 \pm 5.3 \mathrm{a}$ & $161.2 \pm 12.7 \mathrm{a}$ & $62.4 \pm 5.3 \mathrm{a}$ \\
\hline$F_{\text {fertilization }}$ & $* *$ & $* *$ & $*$ & ns \\
\hline \multicolumn{5}{|l|}{ Mean of the years } \\
\hline Control & $95.6 \pm 12.3 b$ & $79.3 \pm 3.5 \mathrm{c}$ & $124.3 \pm 12.7 \mathrm{~b}$ & $49.6 \pm 9.4 \mathrm{~b}$ \\
\hline Compost & $141.8 \pm 21.2 \mathrm{a}$ & $88.2 \pm 5.1 \mathrm{~b}$ & $149.7 \pm 10.2 \mathrm{a}$ & $54.7 \pm 7.6 \mathrm{ab}$ \\
\hline Inorganic fertilizer & $163.0 \pm 24.3 \mathrm{a}$ & $98.5 \pm 6.6 \mathrm{a}$ & $168.0 \pm 16.2 \mathrm{a}$ & $63.6 \pm 3.9 \mathrm{a}$ \\
\hline$F_{\text {fertilization }}$ & $* * *$ & $* * *$ & $* * *$ & $* *$ \\
\hline$F_{\text {year }}$ & ns & ns & ns & $*$ \\
\hline$F_{\text {fertilization } \times \text { year }}$ & ns & ns & ns & ns \\
\hline
\end{tabular}

Values are means \pm standard deviations. Different letters within a column indicate significant differences according to Tukey's HSD test $(p=0.05)$. Significance levels: $* p<0.05 ; * * p<0.01 ; * * * p<0.001$; ns, not significant $(p>0.05)$

yield and its components in the fields treated with organic fertilizers lower than in those treated with inorganic fertilizers (Blatt, 1991).

\section{Fruit yield}

The results of the present study indicated that the effect of organic and inorganic fertilization on fruit yield was significant. Across the years, the highest mean fruit yield $\left(168.0 \mathrm{t} \mathrm{ha}^{-1}\right)$ was observed in the inorganic treatment followed by the organic treatment $\left(149.7 \mathrm{t} \mathrm{ha}^{-1}\right)$. The differences between these treatments were not significant; however, both treatments gave values significantly higher than in the control. Similarly, in other comparative studies, no significant differences in fruit yield had been found between inorganic and organic fertilization (Boček et al., 2008; Murmu et al., 2013). On the other hand, several authors had reported that tomato plants fertilized with inorganic fertilizers produced higher fruit yields because those fertilizers contained soluble inorganic nitrogen and other nutrients with ready availability to crops and therefore helped to produce higher yields (Chassy et al., 2006; Riahi et al., 2009). The average fruit yield had a positive and significant correlation with fruit number and average fruit weight $(r=0.884, p<0.001$ and $r=0.606, p=$ 0.008 , respectively) (Tab. 5).

\section{Average fruit weight}

Regarding the average fruit weight, the combined analysis of variance showed that the fertilization had a significant effect on this trait (Tab. 1). The average fruit weight did not differ among the fertilization treatments in 2016, but it was significantly higher in the inorganic than organic and control plots in 2014 (64.8, 50.2 and $43.4 \mathrm{~g}$ for inorganic and organic fertilization, and the control, respectively). Riahi et al. (2009) had confirmed that the fresh weight of tomato fruits was not affected by organic or conventional fertilization, but significant differences were found among tomato varieties. In addition, Tonfack et al. (2009) conducted an experiment under tropical andosol soil conditions and observed that the mean fruit weight was not influenced by fertilization or cultivars. The differences between those results could be due to the variation in cultivars, soil type, temperature and rainfall during the growing seasons of those experiments.

\section{Fruit diameter}

Fruit diameter was not affected by the different treatments in either year of the study (Tab. 2). Despite that, during the first year the highest values $(40.2 \mathrm{~mm})$ were found in the plots treated with the inorganic fertilizer, while in the second year 
Table 2. Effect of fertilization (control, compost, inorganic fertilizer) on fruit diameter, fruit firmness, total soluble solids (TSS), titratable acidity (TA) and TSS/TA ratio by Tukey's HSD test

\begin{tabular}{|c|c|c|c|c|c|}
\hline Fertilization & $\begin{array}{l}\text { Fruit diameter } \\
(\mathrm{mm})\end{array}$ & $\begin{array}{c}\text { Fruit firmness } \\
\left(\mathrm{kg} \mathrm{cm}^{-2}\right)\end{array}$ & $\begin{array}{c}\text { TSS } \\
\left({ }^{\circ} \text { Brix }\right) \\
\end{array}$ & $\begin{array}{c}\mathrm{TA} \\
(\% \text { citric acid } \mathrm{w} / \mathrm{w})\end{array}$ & TSS/TA \\
\hline \multicolumn{6}{|l|}{ Experiment 2014} \\
\hline Control & $38.0 \pm 0.7 \mathrm{a}$ & $4.08 \pm 0.13 \mathrm{~b}$ & $4.13 \pm 0.04 \mathrm{~b}$ & $0.22 \pm 0.01 \mathrm{a}$ & $18.3 \pm 1.0 \mathrm{a}$ \\
\hline Compost & $38.6 \pm 2.0 \mathrm{a}$ & $4.30 \pm 0.17 \mathrm{ab}$ & $4.34 \pm 0.02 \mathrm{a}$ & $0.24 \pm 0.02 \mathrm{a}$ & $18.2 \pm 0.8 \mathrm{a}$ \\
\hline Inorganic fertilizer & $40.2 \pm 1.7 \mathrm{a}$ & $4.58 \pm 0.24 \mathrm{a}$ & $4.22 \pm 0.03 \mathrm{~b}$ & $0.25 \pm 0.01 \mathrm{a}$ & $16.7 \pm 0.9 \mathrm{a}$ \\
\hline$F_{\text {fertilization }}$ & ns & * & $* *$ & ns & ns \\
\hline \multicolumn{6}{|l|}{ Experiment 2016} \\
\hline Control & $38.2 \pm 2.1 \mathrm{a}$ & $4.40 \pm 0.54 \mathrm{a}$ & $4.08 \pm 0.06 \mathrm{c}$ & $0.29 \pm 0.01 \mathrm{ab}$ & $13.9 \pm 0.4 \mathrm{ab}$ \\
\hline Compost & $39.5 \pm 2.2 \mathrm{a}$ & $4.48 \pm 0.39 \mathrm{a}$ & $4.43 \pm 0.05 \mathrm{a}$ & $0.33 \pm 0.03 \mathrm{a}$ & $16.6 \pm 1.7 \mathrm{a}$ \\
\hline Inorganic fertilizer & $38.4 \pm 2.3 \mathrm{a}$ & $4.63 \pm 0.35 \mathrm{a}$ & $4.27 \pm 0.02 \mathrm{~b}$ & $0.27 \pm 0.02 \mathrm{~b}$ & $13.1 \pm 0.8 \mathrm{~b}$ \\
\hline$F_{\text {fertilization }}$ & ns & ns & $* * *$ & * & $*$ \\
\hline \multicolumn{6}{|l|}{ Mean of the years } \\
\hline Control & $38.1 \pm 1.4 \mathrm{a}$ & $4.24 \pm 0.40 \mathrm{a}$ & $4.11 \pm 0.06 \mathrm{c}$ & $0.26 \pm 0.03 \mathrm{~b}$ & $16.1 \pm 2.5 \mathrm{~b}$ \\
\hline Compost & $39.0 \pm 1.9 \mathrm{a}$ & $4.39 \pm 0.29 \mathrm{a}$ & $4.39 \pm 0.05 \mathrm{a}$ & $0.25 \pm 0.02 \mathrm{~b}$ & $17.4 \pm 1.5 \mathrm{a}$ \\
\hline Inorganic fertilizer & $39.3 \pm 2.1 \mathrm{a}$ & $4.61 \pm 0.26 \mathrm{a}$ & $4.24 \pm 0.03 \mathrm{~b}$ & $0.29 \pm 0.04 \mathrm{a}$ & $14.9 \pm 2.1 \mathrm{~b}$ \\
\hline$F_{\text {fertilization }}$ & ns & $\mathrm{ns}$ & $* * *$ & $* *$ & $* *$ \\
\hline$F_{\text {year }}$ & $\mathrm{ns}$ & ns & $\mathrm{ns}$ & $* * *$ & $* * *$ \\
\hline$F_{\text {fertilization } \times \text { year }}$ & $\mathrm{ns}$ & $\mathrm{ns}$ & $\mathrm{ns}$ & ns & $\mathrm{ns}$ \\
\hline
\end{tabular}

Values are means \pm standard deviations. Different letters within a column indicate significant differences according to Tukey's HSD test $(p=0.05)$. Significance levels: $* p<0.05 ; * * p<0.01 ; * * p<0.001$; ns, not significant $(p>0.05)$

the largest diameter was observed in the organic fruits (39.5 mm). According to Rickman Pieper and Barrett (2008), who studied the effects of organic and conventional cropping systems, the percentage of tomato fruits with a diameter under $3.8 \mathrm{~cm}$ was not affected by the production system. This attribute is dependent on genetic factors linked to cultivars.

\section{Fruit firmness}

Fruit firmness constitutes one of the most important quality traits of the tomatoes processed by the canning industry (Saltveit, 2005). The combined analysis of variance revealed that fruit firmness was not affected by fertilization, with the exception of the first year, where the highest value $(4.58 \mathrm{~kg}$ $\mathrm{cm}^{-2}$ ) was found under the inorganic fertilization treatment (Tab. 2). In another study, an investigation on fruit firmness of conventional and organic tomato fruits had shown that conventional fruits presented significantly higher values compared with the organic ones, but only in some cultivars (Viskelis et al., 2015). Fruit firmness has a tendency to increase until the fertilization rate reaches $80 \mathrm{~kg} \mathrm{~N} \mathrm{ha}^{-1}$, and beyond this value tends to decrease (Erdal et al., 2007). Fruit firmness is negatively associated with the increase of nitrogen content in fruits, since firmness is related to cell turgor and wall characteristics, and the major effect of nitrogen is on fruit growth rate with consistency effects on cell properties (Knee, 2002). Fruit firmness had a positive and significant correlation with average fruit weight and fruit diameter $(r=0.523, p=0.026$ and $r=0.665, p=0.002$, respectively).

\section{Total soluble solids (TSS) and titratable acidity (TA)}

Total soluble solids content is of considerable economic importance for the processing tomato industry, because even a small increase in its value can significantly increase the product yield and decrease the cost of dehydration of puree into sauce and paste (Young et al., 1993). The analysis of variance revealed that total soluble solids were actually affected by fertilization. Specifically, the highest values were found in tomatoes treated with compost (4.34 and $4.43{ }^{\circ}$ Brix in 2014 and 2016, respectively). These results are in full accordance with other studies reporting that tomatoes grown under organic production systems contain higher total soluble solids compared to chemically fertilized crops (Chassy et al. 2006; Barrett et al. 2007; Rickman Pieper and Barrett, 2008). May and Gonzales (1994) had demonstrated an increase in the percentage of soluble solids from 
5.25 to $5.4{ }^{\circ}$ Brix when the nitrogen fertilization rate decreased from 392 to $168 \mathrm{~kg} \mathrm{~N} \mathrm{ha}^{-1}$. Etissa et al. (2014) found that with the increase of nitrogen fertilization rate, the total soluble solids value increased and peaked at a rate of around $100 \mathrm{~kg}$, and beyond this value, the TSS value tended to decrease. Moreover, significant responses to the interaction between fertilization treatment and year were also observed for total soluble solids.

Titratable acidity is an important quality attribute of processing tomatoes since it contributes to the flavour of tomato products. According to the combined analysis, titratable acidity was influenced by fertilization (Tab. 2). This trait did not differ among the fertilization treatments during the first year of the experiment (2014), but significant differences were observed during the second year (2016), with the values being $0.33,0.29$ and $0.27 \%$ for the organic, control and inorganic fertilizer application, respectively. This is in agreement with Toor et al. (2006), who found that tomatoes grown in nitrate-dominant fertilizer solutions had significantly lower values of titratable acidity than those grown with chicken manure, grass/ clover mulch and mineral solutions with lower nitrate to ammonium ratios. Barrett et al. (2007) reported higher titratable acidity in tomatoes grown organically, though not for all the growers in their study. On the other hand, Hallmann (2012) observed that tomatoes grown under organic cropping systems had a significantly lower concentration of organic acids as compared to those cultivated by conventional methods. The year also had a significant effect on titratable acidity, with higher values observed in 2016 as a result of higher temperatures (Wada et al., 1998).

The TSS/TA ratio constitutes a better predictor of the impact of an acid on fruit flavour than soluble solids or acidity alone, since acidity has the tendency to decrease with fruit maturity while sugar content tends to increase (Ilić et al., 2014). This ratio was also affected by the different fertilization regimes. The greatest average values (17.4) were obtained in the organic plots followed by the control (16.1); however, the differences between the treatments were found not to be significant during the first year of the study. The higher values of total soluble solids (TSS), titratable acidity (TA) and TSS/TA ratio under the organic treatment could be related to the increase in vegetative growth of conventional tomato plants. The increase of carbon allocation in the leaves or the increased shading of the fruits due to excess foliage could decrease total soluble solids and titratable acidity (Rickman Pieper and Barrett, 2008).

\section{Fruit surface colour}

Tomato fruit colour constitutes one of the essential and complex quality characteristics of the fruit, with the complexity being due to the presence of a diverse carotenoid pigment system subjected to both genetic and environmental conditions (López Camelo and Gómez, 2004). During the experiment, colour lightness $\left(L^{*}\right)$ was significantly affected by the different fertilization treatments (Tab. 3). The highest value (43.4) was found in the organic fertilization treatment, while the lowest (42.2) was obtained in the untreated plots, indicating that the red colour of organic tomato fruits was lighter. Similarly, Polat et al. (2010) had reported that colour lightness was found to be higher in organic fertilization treatments as compared with inorganic ones. Moreover, the lightness had a positive and significant correlation with total soluble solids $(r=$ $0.602, p=0.008)$ and a negative correlation with titratable acidity $(r=-0.594, p=0.009)$. The $\alpha^{*}$ value is the most indicative of the intensity of red colour, with higher $a^{*}$ values being more desirable in tomatoes (Barrett et al., 2007). Moreover, this colour value has the tendency to increase during tomato ripening, since the red colour is the result of chlorophyll degradation and synthesis of lycopene and other carotenoids, as chloroplasts converted into chromoplasts (Nour et al., 2015). The $a^{*}$ value was significantly different among the fertilization treatments. The data showed that the tomato fruits on the plots treated with compost had the highest values ranging from 34.7 (2014) to 36.1 (2016). These results are in full agreement with those of Viskelis et al. (2015), who investigated three tomato genotypes in greenhouse production using organic and conventional cropping systems and found that the $a^{*}$ value of organic tomato fruits differed by 2.46 from that of the conventionally grown ones. The $a^{*}$ parameter had a positive and significant correlation with total soluble solids $(r=0.716, p<0.001)$. The $b^{*}$ value usually increases from the breaker to turningpink stage, and then decreases until the red stage, since the $\zeta$-carotene (pale yellow) reaches its highest concentration before full maturity (Bhandari and Lee, 2016). In the present study, this value was not significantly influenced by fertilization, with the mean values ranging from 26.4 (control) to 26.9 (organic fertilization). According to the research by López Camelo and Gómez (2004), the $b^{*}$ colour values did not change during the ripening stage, 
Table 3. Effect of fertilization (control, compost, inorganic fertilizer) on fruit surface colour by Tukey’s HSD test

\begin{tabular}{|c|c|c|c|c|c|c|c|c|}
\hline \multirow{3}{*}{$\begin{array}{l}\text { Fertilization } \\
\text { Experiment } 2014\end{array}$} & \multicolumn{8}{|c|}{ Fruit surface colour } \\
\hline & \multicolumn{3}{|c|}{ CIELAB values } & \multicolumn{5}{|c|}{ Colour indices } \\
\hline & $L^{*}$ & $a^{*}$ & $b^{*}$ & CI & $h^{\circ}$ & $\mathrm{C}^{*}$ & $\mathrm{DE}$ & $a * / b^{*}$ \\
\hline Control & $42.7 \pm 0.5 \mathrm{~b}$ & $33.4 \pm 0.2 \mathrm{c}$ & $26.7 \pm 0.7 \mathrm{a}$ & $29.1 \pm 0.9 \mathrm{a}$ & $55.1 \pm 2.0 \mathrm{a}$ & $42.8 \pm 0.6 \mathrm{a}$ & $38.5 \pm 0.4 \mathrm{a}$ & $1.24 \pm 0.03 \mathrm{a}$ \\
\hline Compost & $43.8 \pm 0.2 \mathrm{a}$ & $34.7 \pm 0.2 \mathrm{a}$ & $27.1 \pm 0.5 \mathrm{a}$ & $29.2 \pm 0.4 \mathrm{a}$ & $57.6 \pm 1.4 \mathrm{a}$ & $44.1 \pm 0.4 \mathrm{a}$ & $37.6 \pm 0.3 \mathrm{a}$ & $1.28 \pm 0.02 \mathrm{a}$ \\
\hline Inorganic fertilizer & $42.8 \pm 0.3 \mathrm{~b}$ & $34.0 \pm 0.1 \mathrm{~b}$ & $27.8 \pm 1.2 \mathrm{a}$ & $28.7 \pm 1.3 \mathrm{a}$ & $54.0 \pm 3.6 \mathrm{a}$ & $43.9 \pm 0.8 \mathrm{a}$ & $38.7 \pm 0.8 \mathrm{a}$ & $1.23 \pm 0.05 \mathrm{a}$ \\
\hline$F_{\text {fertilization }}$ & $*$ & $* * *$ & ns & $\mathrm{ns}$ & $\mathrm{ns}$ & ns & $\mathrm{ns}$ & ns \\
\hline Experiment 2016 & $L^{*}$ & $a^{*}$ & $b^{*}$ & $\mathrm{CI}$ & $h^{\circ}$ & $C^{*}$ & $\mathrm{DE}$ & $a * / b^{*}$ \\
\hline Control & $41.6 \pm 0.4 \mathrm{~b}$ & $34.3 \pm 0.4 \mathrm{~b}$ & $25.9 \pm 0.6 \mathrm{a}$ & $31.8 \pm 0.7 \mathrm{a}$ & $61.0 \pm 3.1 \mathrm{a}$ & $43.0 \pm 0.2 \mathrm{~b}$ & $37.4 \pm 0.8 \mathrm{a}$ & $1.33 \pm 0.04 \mathrm{a}$ \\
\hline Compost & $42.9 \pm 0.5 \mathrm{a}$ & $36.1 \pm 0.7 \mathrm{a}$ & $26.7 \pm 0.7 \mathrm{a}$ & $31.5 \pm 1.1 \mathrm{a}$ & $62.9 \pm 2.6 \mathrm{a}$ & $44.9 \pm 0.8 \mathrm{a}$ & $36.5 \pm 0.5 \mathrm{a}$ & $1.35 \pm 0.03 \mathrm{a}$ \\
\hline Inorganic fertilizer & $42.2 \pm 0.4 \mathrm{ab}$ & $34.6 \pm 0.2 \mathrm{~b}$ & $25.6 \pm 0.3 \mathrm{a}$ & $32.0 \pm 0.7 \mathrm{a}$ & $62.8 \pm 1.7 \mathrm{a}$ & $43.0 \pm 0.4 \mathrm{~b}$ & $36.9 \pm 0.3 \mathrm{a}$ & $1.35 \pm 0.02 \mathrm{a}$ \\
\hline$F_{\text {fertilization }}$ & $*$ & $* *$ & ns & ns & ns & $* *$ & ns & ns \\
\hline Mean of the years & $L^{*}$ & $a^{*}$ & $b^{*}$ & $\mathrm{CI}$ & $h^{\circ}$ & $\mathrm{C}^{*}$ & $\mathrm{DE}$ & $a^{*} / b^{*}$ \\
\hline Control & $42.2 \pm 0.7 \mathrm{~b}$ & $33.8 \pm 0.6 \mathrm{~b}$ & $26.4 \pm 0.8 \mathrm{a}$ & $30.5 \pm 1.7 \mathrm{a}$ & $58.1 \pm 3.9 \mathrm{a}$ & $42.9 \pm 0.4 \mathrm{~b}$ & $38.0 \pm 0.8 \mathrm{a}$ & $1.28 \pm 0.05 \mathrm{a}$ \\
\hline Compost & $43.4 \pm 0.6 \mathrm{a}$ & $35.4 \pm 0.9 \mathrm{a}$ & $26.9 \pm 0.6 \mathrm{a}$ & $30.3 \pm 1.5 \mathrm{a}$ & $60.3 \pm 3.4 \mathrm{a}$ & $44.5 \pm 0.8 \mathrm{a}$ & $37.1 \pm 0.7 \mathrm{a}$ & $1.32 \pm 0.04 \mathrm{a}$ \\
\hline Inorganic fertilizer & $42.5 \pm 0.5 \mathrm{~b}$ & $34.3 \pm 0.3 \mathrm{~b}$ & $26.7 \pm 1.4 \mathrm{a}$ & $30.4 \pm 2.1 \mathrm{a}$ & $58.4 \pm 5.4 \mathrm{a}$ & $43.5 \pm 0.7 \mathrm{~b}$ & $37.8 \pm 1.1 \mathrm{a}$ & $1.29 \pm 0.08 \mathrm{a}$ \\
\hline$F_{\text {fertilization }}$ & $* * *$ & $* * *$ & ns & $\mathrm{ns}$ & ns & $* *$ & $\mathrm{~ns}$ & ns \\
\hline$F_{\text {year }}$ & $* * *$ & $* * *$ & $* *$ & $* * *$ & $* * *$ & ns & $* * *$ & $* * *$ \\
\hline$F_{\text {fertilization } \times \text { year }}$ & ns & ns & ns & ns & ns & ns & ns & ns \\
\hline
\end{tabular}

$L^{*}=$ colour lightness, $a^{*}=$ colour index, $b^{*}=$ colour index, $\mathrm{CI}=$ colour index, $h^{\circ}=$ hue angle, $C^{*}=$ chroma, $\mathrm{DE}=$ colour difference with true red. Values are means \pm standard deviations. Different letters within a column indicate significant differences according to Tukey's HSD test $(p=0.05)$. Significance levels: * $p<0.05 ; * *<<0.01 ; * * p<0.001$; ns, not significant $(p>0.05)$

Table 4. Effect of fertilization (control, compost, inorganic fertilizer) on lycopene content and lycopene yield by Tukey's HSD test

\begin{tabular}{lcc}
\hline Fertilization & $\begin{array}{c}\text { Lycopene content } \\
\left(\mathrm{mg} \mathrm{kg}^{-1} \text { fresh weight }\right)\end{array}$ & $\begin{array}{c}\text { Lycopene yield } \\
\left(\mathrm{kg} \mathrm{ha}^{-1}\right)\end{array}$ \\
\hline Experiment 2014 & $77.0 \pm 0.8 \mathrm{~b}$ & $9.7 \pm 0.9 \mathrm{~b}$ \\
Control & $87.0 \pm 4.0 \mathrm{a}$ & $13.0 \pm 1.1 \mathrm{a}$ \\
Compost & $79.6 \pm 3.5 \mathrm{ab}$ & $13.9 \pm 1.1 \mathrm{a}$ \\
Inorganic fertilizer & $* *$ & $* *$ \\
$F_{\text {fertilization }}$ & & $9.1 \pm 1.3 \mathrm{~b}$ \\
Experiment 2016 & $74.3 \pm 2.5 \mathrm{c}$ & $13.5 \pm 1.1 \mathrm{a}$ \\
Control & $89.9 \pm 2.6 \mathrm{a}$ & $13.1 \pm 0.8 \mathrm{a}$ \\
Compost & $81.4 \pm 1.6 \mathrm{~b}$ & $* *$ \\
Inorganic fertilizer & $* * *$ & \\
$F_{\text {fertilization }}$ & & $9.4 \pm 1.0 \mathrm{~b}$ \\
Mean of the years & $75.6 \pm 2.2 \mathrm{c}$ & $13.2 \pm 1.1 \mathrm{a}$ \\
Control & $88.5 \pm 3.4 \mathrm{a}$ & $13.5 \pm 1.0 \mathrm{a}$ \\
Compost & $80.5 \pm 2.62 \mathrm{~b}$ & $* * *$ \\
Inorganic fertilizer & $* * *$ & $\mathrm{~ns}$ \\
$F_{\text {fertilization }}$ & $\mathrm{ns}$ & $\mathrm{ns}$ \\
$F_{\text {year }}$ & $\mathrm{ns}$ & \\
$F_{\text {fertilization } \times \text { year }}$ & &
\end{tabular}

Values are means \pm standard deviations. Different letters within a column indicate significant differences according to Tukey's HSD test $(p=0.05)$. Significance levels: $* p<0.05 ; * * p<0.01 ; * * * p<0.001 ;$ ns, not significant $(p>0.05)$ 
although values were slightly higher at the pinklight red stage. Rickman Pieper and Barrett (2008) conducted an experiment and found that the organic tomato fruits had significantly higher $b^{*}$ values than the conventional ones, and explained that the organic fruits were less ripe. The $b^{*}$ parameter had a negative and significant correlation with titratable acidity $(r=-0.554 . p=0.017)$.

Concerning the colour indices, the $a^{*} / b^{*}$ index, hue angle, colour index and colour difference did not differ among the fertilization regimes. Despite the absence of a significant influence of fertilization regimes on these indices, the highest mean values of $a^{*} / b^{*}(1.32)$ and hue angle (60.3) were observed in organic plots, while the highest colour index (30.6) and colour difference (38.0) were obtained under the inorganic treatment and control, respectively. Chassy et al. (2006) had reported that the $a^{*} / b^{*}$ values were slightly lower in organic production systems than conventional ones, but the difference was not significant. The $a * / b *$ index had a positive and significant correlation with titratable acidity $(r=0.614, p=0.006)$; however, the expected strong correlation with lycopene content $(r=0.301, p=$ 0.101 ) was not observed as in other studies (Nour et al., 2015). Some researchers, measuring this index on the fruit skin, did not find the existence of any direct correlation with lycopene content since the same $a^{*} / b^{*}$ value could correspond to lycopene contents differing 100\% (Dumas et al., 2003). Concerning hue, a two-year experiment had been conducted and it was observed that during the first year the hue angle was significantly affected by organic and conventional fertilization treatments, and the lowest value (reddish) was found in conventionally grown tomatoes (Polat et al., 2010). Chroma is another colour index that reflects colour saturation and increases during the ripening of tomato fruits (Nour et al., 2015). With the exception of the first year (2014), chroma was significantly affected by fertilization, and the fruits harvested from the organic plots presented the highest value (44.9 in 2016). Finally, as regards the effect of the year on fruit surface colour, it had a great impact on the colour parameters and indices. The higher mean air temperature in the fruiting stage during the second year of the study resulted in more reddish tomato fruits (Vogele, 1937).

\section{Lycopene content and lycopene yield}

As mentioned above, lycopene, the red pigment of tomato, is the most important tomato carotenoid because of its antioxidant activity against chronic illnesses, including cardiovascular diseases and a broad range of epithelial cancers. The results on lycopene content showed a significant variation among the fertilization treatments (Tab. 4). In particular, the highest lycopene content was achieved in the organic fertilization treatment (88.5 $\mathrm{mg} \mathrm{kg}^{-1}$ f.w.), followed by the inorganic (80.5 mg kg-1 f.w.) and control (75.6 $\mathrm{mg} \mathrm{kg}^{-1}$ f.w.) treatments. These results are in line with those of Rickman Pieper and Barrett (2008), who reported that higher levels of lycopene, on a fresh weight basis, were found in organically grown tomatoes. With the increase of plant-available nitrogen came increased vegetative growth, which in turn increased shading and hence reduced the solar radiation and temperature for tomato fruits, consequently reducing the lycopene content (Knee, 2002). During recent years, the interest of processing industries to make products with a high lycopene content, as well as the interest of pharmaceutical and cosmetic industries to use lycopene in their products, have increased the need for tomatoes with a high lycopene content in order to reduce the extraction costs. The lycopene content in processing tomato cultivars ranges between 40 and $80 \mathrm{mg} \mathrm{kg}^{-1}$ fresh weight (Cantore et al., 2008). Our results revealed that organic processing tomatoes can be used for lycopene production. The lycopene content had a positive and significant correlation with total soluble solids, $L^{*}$ and $a^{*}(r=0.889, p<0.001$, $r=0.597, p=0.008$ and $r=0.699, p=0.002$, respectively) and some colour indices such as chroma and colour difference $(r=0.633, p=0.005$ and $r=-0.476, p=0.041$ ).

Regarding the lycopene yield, the highest yield $\left(13.5 \mathrm{~kg} \mathrm{ha}^{-1}\right)$ was recorded in the inorganic fertilization treatment followed by the organic treatment $\left(13.2 \mathrm{~kg} \mathrm{ha}^{-1}\right)$ with no statistical differences between them. The highest lycopene yield obtained in the inorganically fertilized plots was due to the fact that this value depends on fruit yield, and the greatest fruit yield was obtained under the inorganic treatment. As shown in Table 5, lycopene yield had a positive and significant correlation with fruit number, fruit weight and fruit yield $(r=0.797, p$ $<0.001 ; r=0.533, p=0.022 ; r=0.919, p<0.001)$.

\section{CONCLUSIONS}

The results of the present study indicate that the yield and quality characteristics of processing tomato crops were affected by fertilization. The highest dry weight per plant, fruit number per plant, average fruit weight and fruit yield were observed following 


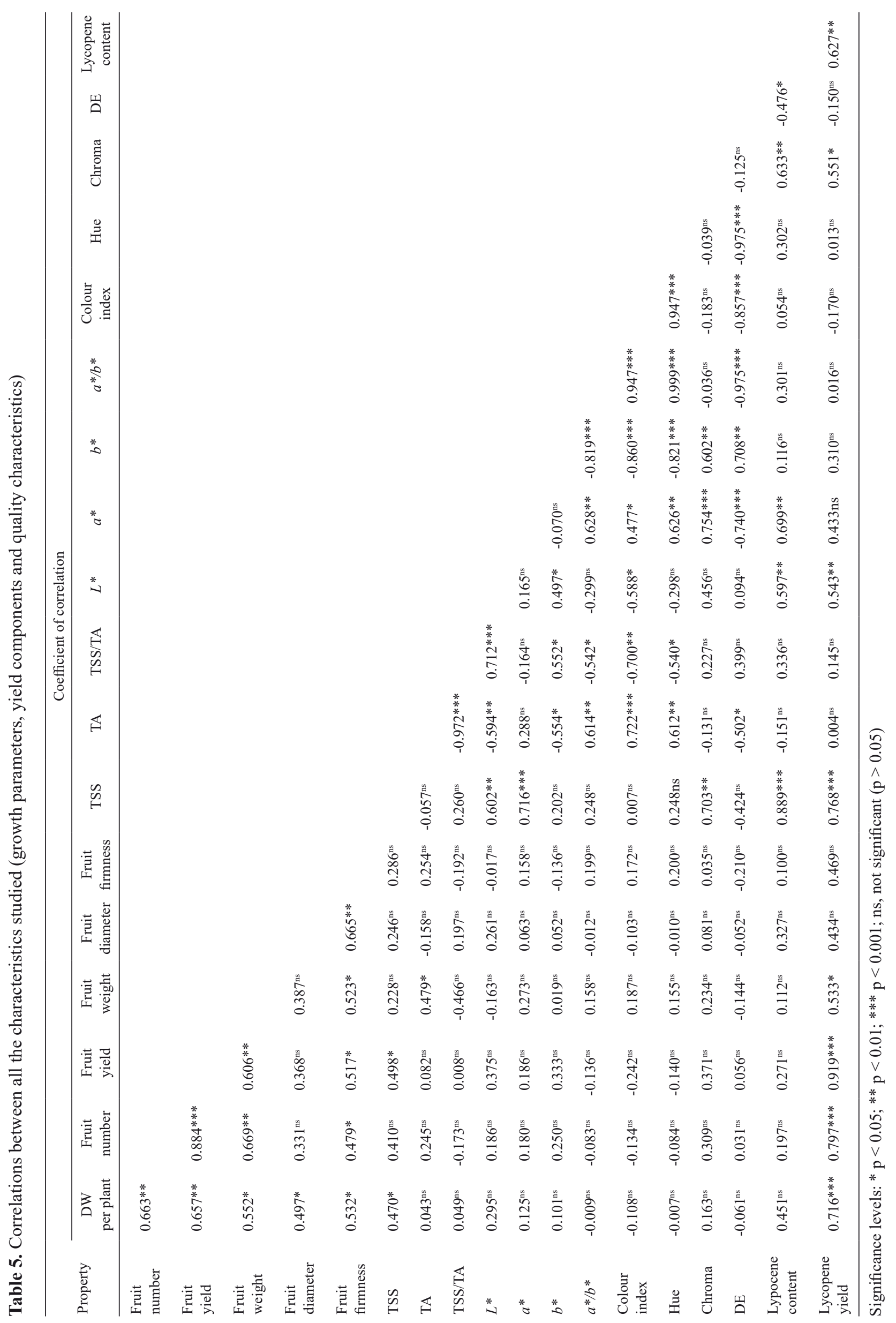


the application of the inorganic fertilizer. In terms of fruit diameter and fruit firmness, there were no significant differences between the fertilization treatments. Among the colour parameters, only the $L^{*}$ and $a^{*}$ values were influenced by the application of fertilizers, with the highest values found in the organic treatment. With the exception of the year 2014, the chroma index had the highest value in the organic treatment, while the other colour indices were found not to differ among the treatments regardless of the year. Significantly higher total soluble solids and total soluble solids to titratable acidity ratio found in organically grown tomatoes are particularly important to the processing tomato industry. Finally, the highest lycopene content produced under organic fertilization as well as the non-significant difference between the organic and conventional tomatoes in terms of lycopene yield make organic processing tomatoes suitable for lycopene production. There is a clear need to continue this study as a long-term experiment in order to investigate the effect of seasonality.

\section{ACKNOWLEDGEMENT}

The authors wish to record their sincere thanks to Aristotle Kyritsis, agronomist, and D. NomikosCopais S.A. tomato processing company for providing the tomato seedlings.

\section{FUNDING}

The search was supported by the Laboratory of Agronomy, Agricultural University of Athens.

\section{AUTHOR CONTRIBUTIONS}

All authors contributed equally to the design and implementation of the research, to the analysis of the results and to the writing of the manuscript.

\section{CONFLICT OF INTEREST}

Authors declare no conflict of interest.

\section{REFERENCES}

Akdeniz B., Demirbüker Kavak B., AĞdatlioĞlu N., 2012. Use of factorial experimental design for analyzing the effect of storage conditions on color quality of sun-dried tomatoes. Sci. Res. Essays 7(4), 477-489.

Barrett D.M., Weakley C., DiaZ J.V., Watnik M., 2007. Qualitative and nutritional differences in processing tomatoes grown under commercial organic and conventional production systems. J. Food Sci. 72(9), C441-451.
BhANDARI S.R., LeE J.G., 2016. Ripening-dependent changes in antioxidants, color attributes, and antioxidant activity of seven tomato (Solanum lycopersicum L.) cultivars. J. Anal. Methods Chem. 5498618, doi: 10.1155/2016/5498618

Bilalis D., Kamariari P.-E., Karkanis A., Efthimiadou A., Zorpas A., KaKabouKi I., 2013. Energy inputs, output and productivity in organic and conventional maize and tomato production, under Mediterranean conditions. Not. Bot. Horti Agrobot. Cluj Napoca 41(1), 190-194.

Blatt C.R., 1991. Comparison of several organic amendments with a chemical fertilizer for vegetable production. Sci. Hortic. 47, 177-191.

BočeK S., Maly I., PATOČKová Š., 2008. Yield and quality of bush processing tomatoes fertilized with dried organic and organomineral fertilizers. Acta Univ. Agric. Silvic. Mendel. Brun. 56(2), 31-38.

Cantore V., Boari F., Vanadia S., Pace B., De Palma E., LEO L., ET AL., 2008. Evaluation of yield and qualitative parameters of high lycopene tomato cultivars. Acta Hortic. 789, 173-180.

Chassy A.W., Bui L., Renaud E.N., Van Horn M., Mitchell A.E., 2006. Three-year comparison of the content of antioxidant microconstituents and several quality characteristics in organic and conventionally managed tomatoes and bell peppers. J. Agric. Food Chem. 54, 8244-8252.

Cheimona N., Angeli C., Panagiotou E., Tzanidaki A., Dronza C., Travlos I., et al., 2016. Effect of different types of fertilization on weed flora in processed tomato crop. Agric. Agric. Sci. Procedia 10, 26-31.

Dumas Y., Dadomo M., Di Lucca G., Grolier P., 2003. Effects of environmental factors and agricultural techniques on antioxidant content of tomatoes. J Sci. Food Agric. 83, 369-382.

Egan H., Kirk R.S., Sawyer R., 1981. Pearson`s Chemical Analysis of Foods, $8^{\text {th }}$ edition. Churchill Livingstone, Edinburgh, UK.

EC 834/2007. Council Regulation (EC) No. 834/2007 of 28 June 2007 on organic production and labeling of organic products and repealing Regulation (EEC) No. 2092/91. The Council of the European Union.

Eн A., TeOH S.-G., 2012. Novel modified ultrasonication technique for the extraction of lycopene. Ultrason. Sonochem. 19(1), 151-159.

Elia A., Conversa G., 2012. Agronomic and physiological responses of a tomato crop to nitrogen input. Eur. J. Agron. 40, 64-74.

Erdal I., Ertek A., Senyigit U., Koyuncu M.A., 2007. Combined effects of irrigation and nitrogen on some quality parameters of processing tomato. World J. Agric. Sci. 3, 57-62.

Etissa E., Dechassa N., Alamirew T., Alemayehu Y., Dessalegne L., 2014. Response of fruit quality of tomato grown under varying inorganic $\mathrm{N}$ and $\mathrm{P}$ fertilizer rates under furrow irrigated and rainfed 
production conditions. Int. J. Dev. Sustain. 3(2), 371387.

Fish W.W., Perkins-Veazie P., Collins J.K., 2002. A quantitative assay for lycopene that utilizes reduced volumes of organic solvents. J. Food Comp. Anal. 15(3), 309-317.

Hallmann E., 2012. The influence of organic and conventional cultivation systems on the nutritional value and content of bioactive compounds in selected tomato types. J. Sci. Food Agric. 92(14), 2840-2848.

Ilić Z.S., Kapoulas N., Šunić L., 2014. Tomato fruit quality from organic and conventional production, In: Organic Agriculture Towards Sustainability. V. Pilipavicius (Ed.), InTech Open. doi:10.5772/57033.

Jimenez-Cuesta M., CuQuerella J., Martinz-Javaga J.M., 1981. Determination of a color index for citrus fruits degreening. Proc. International Society of Citriculture. International Citrus Congress. 9-12 November, Tokyo, 750-753.

KNEE M., 2002. Fruit Quality and Its Biological Basis. Sheffield Academic Press, Sheffield, UK.

LeE M.T., Chen B.H., 2011. Separation of lycopene and its cis isomers by liquid chromatography. Chromatographia 54, 613-617.

Little A.C., 1975. A research note off on a tangent. J. Food Sci. 40(2), 410-411.

López Camelo A.F., Gómez P.A., 2004. Comparison of color indexes for tomato ripening. Hortic. Bras. 22(3), 534-537.

May D.M., GonZales J., 1994. Irrigation and nitrogen management as they affect fruit quality and yield of processing tomatoes. Acta Hortic. 376, 227-234.

MCGuiRe R.G., 1992. Reporting of objective color measurements. HortScience 27(12), 1254-1255.

Murmu K., Ghosh B.C., Swain D.K., 2013. Yield and quality of tomato grown under organic and conventional nutrient management. Arch. Agron. Soil Sci. 59(10), 1311-1321.

Nour V., Ionica M.E., Trandafir I., 2015. Bioactive compounds, antioxidant activity and color of hydroponic tomato fruits at different stages of ripening. Not. Bot. Horti. Agrobot. Cluj Napoca 43(2), 404-412.

Perveen R., Suleria H.A., Anjum F.M., Butt M.S., Pasha I., Ahmad S., 2015. Tomato (Solanum lycopersicum) carotenoids and lycopenes chemistry; metabolism, absorption, nutrition, and allied health claims A comprehensive review. Crit. Rev. Food Sci. Nutr. 55(7), 919-929.

Polat E., Demir H., Erler F., 2010. Yield and quality criteria in organically and conventionally grown tomatoes in Turkey. Sci. Agric. 67(4), 424-429.

Riahi A., Hdider C., SanaA M., Tarchoun N., Kheder M.B., Guezal I., 2009. Effect of conventional and organic productions systems on the yield and quality of field tomato cultivars grown in Tunisia. J. Sci. Food Agric. 89, 2275-2282.

Rickman Pieper J., Barrett D.M., 2008. Effects of organic and conventional production systems on quality and nutritional parameters of processing tomatoes. J Sci. Food Agric. 89, 177-194.

Rinaldi M., Convertini G., Elia A., 2007. Organic and mineral nitrogen fertilization for processing tomato in southern Italy. Acta Hortic. 758, 241-247.

Sadler G., Davis J., Dezman D., 1990. Rapid extraction of lycopene and $\beta$-carotene from reconstituted tomato paste and pink grapefruit homogenates. J. Food Sci. $55,1460-1461$.

Sadler G.D., MurPhy P.A., 2010. pH and titratable acidity. In: Food Analysis, $4^{\text {th }}$ edition. S.S. Nielsen (Ed.), Springer, New York, USA, 219-238.

SALtVEIT M.E., 2005. Fruit ripening and fruit quality, In: Tomatoes. E. Heuvelink (Ed.), CABI Publishing, Cambridge, USA, 145-170.

Tei F., Benincasa P., Guiducci M., 2002. Critical nitrogen concentration in processing tomato. Eur. J. Agron. 18, 45-55.

Tonfack L.B., Bernadac A., Youmbi E., Mbouapouognigni V.P., Ngueguim M., Akoa A., 2009. Impact of organic and inorganic fertilizers on tomato vigor, yield and fruit composition under tropical andosol soil condition. Fruits 64, 167-177.

Toor R.K., Savage G.P., Heeb A., 2006. Influence of different types of fertilizers on the major antioxidant components of tomatoes. J. Food Compos. Anal. 19, 20-27.

VisKelis P., RadZEVICIUS A., URbONAVICIENE D., VisKelis J., Karkleliene R., Bobinas C., 2015. Biochemical parameters in tomato fruits from different cultivars as functional foods for agricultural, industrial, and pharmaceutical uses. In: Plants for the future. H. ElShemy (Ed.), InTech Open, doi: 10.5772/60873.

VoGele A.C., 1937. Effect of environmental factors upon the color of the tomato and the watermelon. Plant Physiol. 12(4), 929-955.

Wada T., Ikeda H., Morimoto K., Furukawa H., 1998. Effects of minimum air temperatures on the growth, yield and quality of tomatoes grown on a single-truss system. J. Jpn. Soc. Hortic. Sci. 67(3), 420-425.

Young T.E., JuviK J.A., Sullivan J.G., 1993. Accumulation of the components of total solids in ripening fruits of tomato. J. Am. Soc. Hortic. Sci. 118, 286-292.

Received December 5, 2017; accepted June 15, 2018 